\title{
The effect of provision of the first-limiting amino acid, gastrointestinal microbial activity and the level of nitrogen intake on protein utilization and energy digestibility in rats
}

\author{
BY B. O. EGGUM ${ }^{1}$, R. M. BEAMES ${ }^{2}$ AND K. E. BACH KNUDSEN ${ }^{1}$ \\ ${ }^{1}$ National Institute of Animal Science, Animal Physiology and Biochemistry, \\ 25 Rolighedsvej, DK-1958 Copenhagen V, Denmark \\ ${ }^{2}$ Department of Animal Science, University of British Columbia, \\ Vancouver BC, Canada V6T $2 A 2$
}

(Received 28 January 1985 - Accepted 4 July 1985)

1. The present work with growing rats was undertaken to study the effect of protein quality, gastrointestinal microbial activity and the level of nitrogen intake on protein utilization and energy digestibility. The experiment involved a total of thirty-six dietary treatments in a $9 \times 4$ factorial design, with five rats per treatment. The thirty-six diets resulted from nine protein sources. Each diet was composed of a basal $\mathrm{N}$-free mixture plus minerals and vitamins, with $\mathrm{N}$ sources added at the expense of the $\mathrm{N}$-free mixture to provide $15.0 \mathrm{~g} \mathrm{~N} / \mathrm{kg}$ dry matter (DM) in the first three protein-addition treatments and $30.0 \mathrm{~g} \mathrm{~N} / \mathrm{kg} \mathrm{DM}$ in the fourth protein-addition treatment. The nine protein sources were soya-bean meal, casein, wheat gluten, skim-milk powder, meat-and-bone meal, wheat bran, barley, wheat and cooked brown beans (Phaseolus vulgaris). The four formulations for each protein source incorporated the protein unsupplemented at $15.0 \mathrm{gN} / \mathrm{kg} \mathrm{DM}$, unsupplemented at $30.0 \mathrm{~g} \mathrm{~N} / \mathrm{kg} \mathrm{DM}$, or supplemented at $15.0 \mathrm{~g} \mathrm{~N} / \mathrm{kg} \mathrm{DM}$ with the estimated first-limiting amino acid or the antibiotic Nebacitin.

2. With all protein sources, the inclusion of the first-limiting amino acid had no effect on either protein or energy digestibility.

3. The microbial activity in the digestive tract affected protein utilization and energy digestibility to a different degree depending primarily on the level and type of dietary fibre. True protein digestibility (TD) of skim-milk powder and brown beans, both rich in easily-fermentable energy, increased from 0.959 to 1.000 and from 0.680 to 0.777 respectively by the addition of Nebacitin. TD of the other protein sources was only marginally affected by the antibiotic treatment. Only with brown beans was the biological value (BV) markedly affected by Nebacitin with an increase from 0.482 to 0.557 by the treatment. Energy digestibility was significantly lower in rats given antibiotic with soya-bean meal, wheat bran, barley, wheat and brown beans

4. The effect of level of $\mathrm{N}$ intake on protein utilization was dependent on both protein quality and the fibre concentration of the diet. Protein sources with high BV were more affected than proteins of lower BV. It was concluded that TD is not always independent of dietary protein concentration.

Earlier work by Eggum et al. (1984) demonstrated that supplementation of the basal diet with the limiting amino acid not only improved biological value (BV) but also true protein digestibility (TD). This is in agreement with the results of Tao et al. (1971), Gruhn (1976) and Ostrowski (1975) who have shown that lysine supplementation of lysine-deficient diets can improve TD. This slight elevation in TD could have been due to a lower urea diffusion into the gut as a result of a reduction of blood urea levels associated with the amino acid supplementation. The simultaneous elevation of BV (Eggum et al. 1984) supports this hypothesis.

There is no doubt that the presence of a population of micro-organisms in the alimentary tract of single-stomached animals and man can affect nitrogen metabolism and that this effect under certain conditions will be significant. Several experiments have shown that the intestinal flora can degrade amino acids, amides, urea, etc. (Michel, 1966) as well as carbohydrates (Mason, 1980). The metabolic activity of hind-gut micro-organisms is thus well documented. The type and extent of fermentation is strongly influenced by the efficiency with which food is digested and absorbed in the upper tract (Bach Knudsen et al. 1984; Eggum et al. 1984). In addition to their degradation activity, the microflora of the caecum 
and the large intestine assimilate nitrogenous materials into their cell components. It is known, moreover, that in addition to their responses to the type and quantity of dietary $\mathrm{N}$, faecal $\mathrm{N}$ excretion by single-stomached animals is influenced by the amount and type of fibre, starch and sucrose in the diet (Mason, 1978; Rerat, 1978).

Information on the form of the $\mathrm{N}$ absorbed from the large intestine is still incomplete. It appears that most of this $\mathrm{N}$ is absorbed as ammonia (Hoover \& Heitmann, 1975) although under most conditions amine production and absorption may be appreciable (Milne \& Asatoor, 1975). Undoubtedly, some of the ammonia arises from the degradation of urea, which is present in various body fluids in approximately equal concentrations (Chalmers et al. 1976) and diffuses freely into the gastrointestinal tract (Rerat et al. 1979). Studies with germ-free rats confirm that this compound diffuses into the alimentary canal in appreciable quantities (Combe \& Sacquet, 1966). Thus, net absorption of $\mathrm{N}$ in the hind-gut represents the balance between the processes of degradation and assimilation reached by the microflora during the period of fermentation.

In order to study the effect of dietary protein level on protein utilization, Eggum (1973) carried out experiments with rats given increasing amounts of protein from casein $+10 \mathrm{~g}$ DL-methionine $/ \mathrm{kg}$ and from soya-bean meal. The conclusion from these experiments was that TD is independent of dietary protein level, whereas apparent protein digestibility (AD) and $\mathrm{BV}$ are dependent on dietary level.

The present experiment was designed to study the effect of protein quality and dietary level on $\mathrm{N}$ and energy utilization in rats, and to investigate the role of bacterial fermentation by the use of the antibiotic Nebacitin. Correction of faecal values for the $\mathrm{N}$ contribution from Nebacitin was performed as described by Mason et al. (1982). When Nebacitin was subjected to both three- and four-enzyme in vitro digestibility (Pedersen \& Eggum, 1981) no digestion was observed. Nine different protein sources of animal or plant origin were included in the study.

\section{EXPERIMENTAL}

\section{Diets}

The experiment involved a total of thirty-six dietary treatments in a $9 \times 4$ factorial design, with five rats per treatment. The thirty-six diets resulted from nine protein sources with each incorporated by the use of four formulating methods (Table 1). Each diet was composed of a basal N-free mixture containing (g/ $\mathrm{kg}$ air-dry matter) sucrose $89 \cdot 2$, cellulose $52 \cdot 0$, peanut oil 52.0 and autoclaved potato starch 806.8 , plus minerals and vitamins (Eggum, 1973), with $\mathrm{N}$ sources added at the expense of the $\mathrm{N}$-free mixture to provide $15.0 \mathrm{~g} \mathrm{~N} / \mathrm{kg}$ dry matter (DM) in the first three protein-addition treatments and where possible $30.0 \mathrm{~g} \mathrm{~N} / \mathrm{kg} \mathrm{DM}$ in the fourth protein-addition treatment. The nine protein sources were soya-bean meal, casein, wheat gluten, skim-milk powder, meat-and-bone meal, wheat bran, barley, wheat and autoclaved brown beans (Phaseolus vulgaris). The brown beans were mixed with water $(3: 1, \mathrm{w} / \mathrm{w})$ and autoclaved at $203 \mathrm{kPa}(2 \mathrm{~atm})$ for $3 \mathrm{~h}$ and then dried for $3 \mathrm{~h}$. The four formulations for each protein source incorporated the protein unsupplemented at $15.0 \mathrm{~g} \mathrm{~N} / \mathrm{kg} \mathrm{DM}$, unsupplemented at $30.0 \mathrm{~g} \mathrm{~N} / \mathrm{kg} \mathrm{DM}$, or supplemented at $15.0 \mathrm{~g} \mathrm{~N} / \mathrm{kg}$ DM with the estimated first-limiting amino acid or the antibiotic Nebacitin.

\section{Animals and feeding}

The experimental procedure has been described by Eggum (1973). Groups of five Wistar male rats weighing approximately $70 \mathrm{~g}$ were used, with a preliminary period of $4 \mathrm{~d}$ and a balance period of $5 \mathrm{~d}$. For formulations 1,2 and 3 each rat received $150 \mathrm{mg} \mathrm{N}$ and $10 \mathrm{~g}$ DM daily throughout the preliminary and the balance periods, while rats on formulation 4 received $300 \mathrm{mg} \mathrm{N}$ and $10 \mathrm{~g} \mathrm{DM}$ daily, except for the wheat-bran-, wheat- and barley-based 
Table 1. Composition of diets incorporating protein from nine sources provided at a level of $15 \mathrm{~g}$ nitrogen $/ \mathrm{kg}$ dry matter $(D M)$ with no additive, with the addition of the assumed first-limiting amino acid and with the antibiotic Nebacitin and at a level of $30 \mathrm{~g} \mathrm{~N} / \mathrm{kg} \mathrm{DM*}$

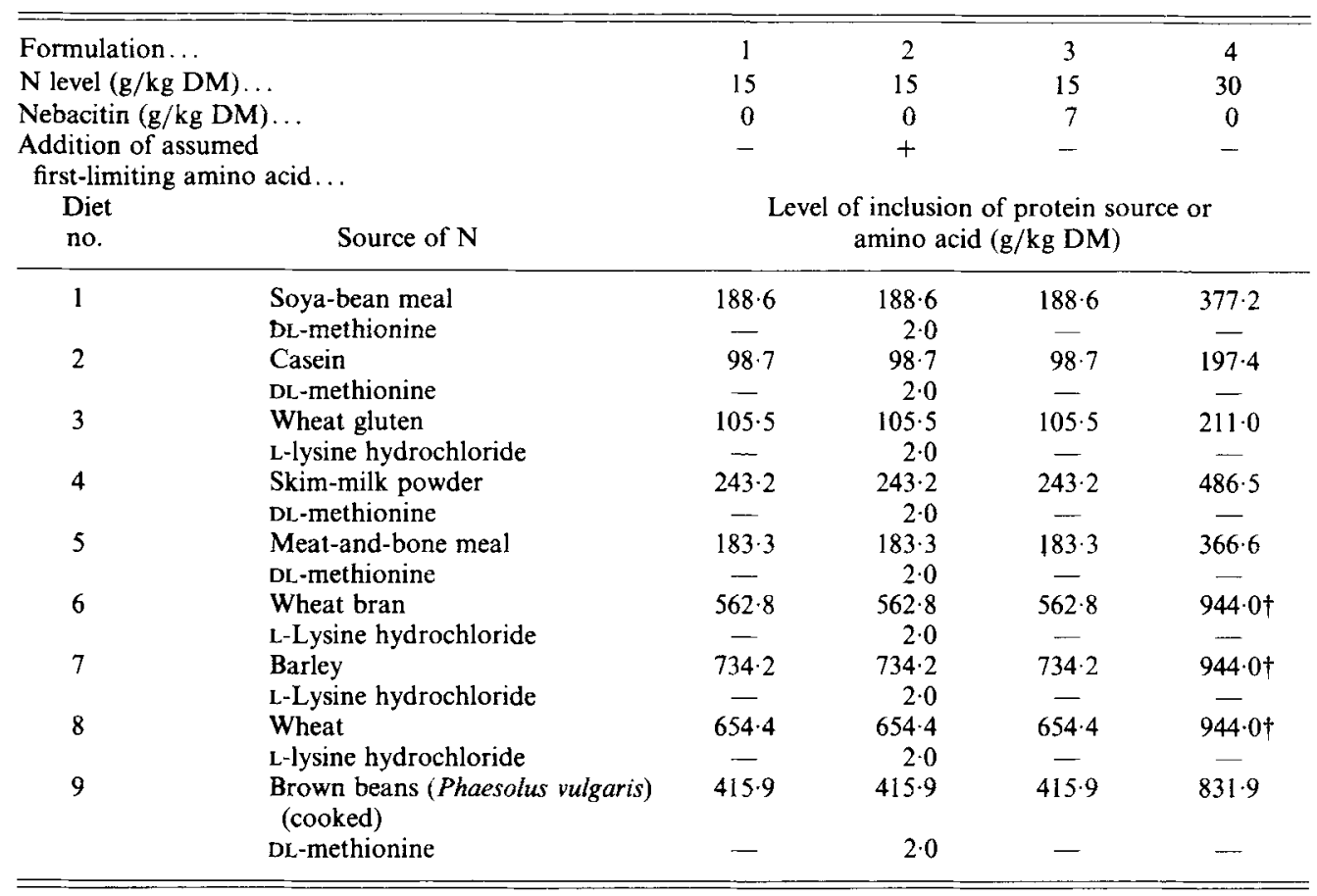

* All diets contained $40 \mathrm{~g}$ mineral mixture, $16 \mathrm{~g}$ vitamin mixture and sufficient $\mathrm{N}$-free mixture to produce a total formula weight of $1 \mathrm{~kg}$. Compositions of these mixtures are according to Eggum (1973).

$\dagger$ For diets 6,7 and 8 , the $\mathrm{N}$ concentration of the protein source was too low to provide $30 \mathrm{~g} \mathrm{~N} / \mathrm{kg} \mathrm{DM}$. The levels were 25,19 and $22 \mathrm{~g} \mathrm{~N} / \mathrm{kg}$ DM for wheat bran, barley and wheat respectively. Level of inclusion was maximum possible after inclusion of minerals and vitamins.

diets. AD, TD, BV, net protein utilization (NPU) and energy digestibility (DE) were measured. The values presented for DE are for the protein sources alone, with corrections made for the DE of the basal diet, which had been determined previously.

\section{Chemical analyses}

The chemical composition of the samples was determined according to standard methods (Association of Official Analytical Chemists, 1975) with the exception that acid-hydrolysis followed by diethyl ether extraction was used for the estimation of fat (Stoldt, 1952) while an enzymic assay (Asp et al. 1983) was used to measure the different forms of fibre. According to this procedure total dietary fibre (TDF) can be partitioned into soluble (SDF) and insoluble (IDF) dietary fibre components. Amino acid analyses were carried out according to Mason et al. (1980).

\section{Statistical analyses}

All results were subjected to analysis of variance as outlined in the University of British Columbia program BMD : 10V (Bjerring et al. 1975). All differences between means were tested at $P<0.05$, using the Newman-Keul's multiple range test included in the previouslymentioned program. 


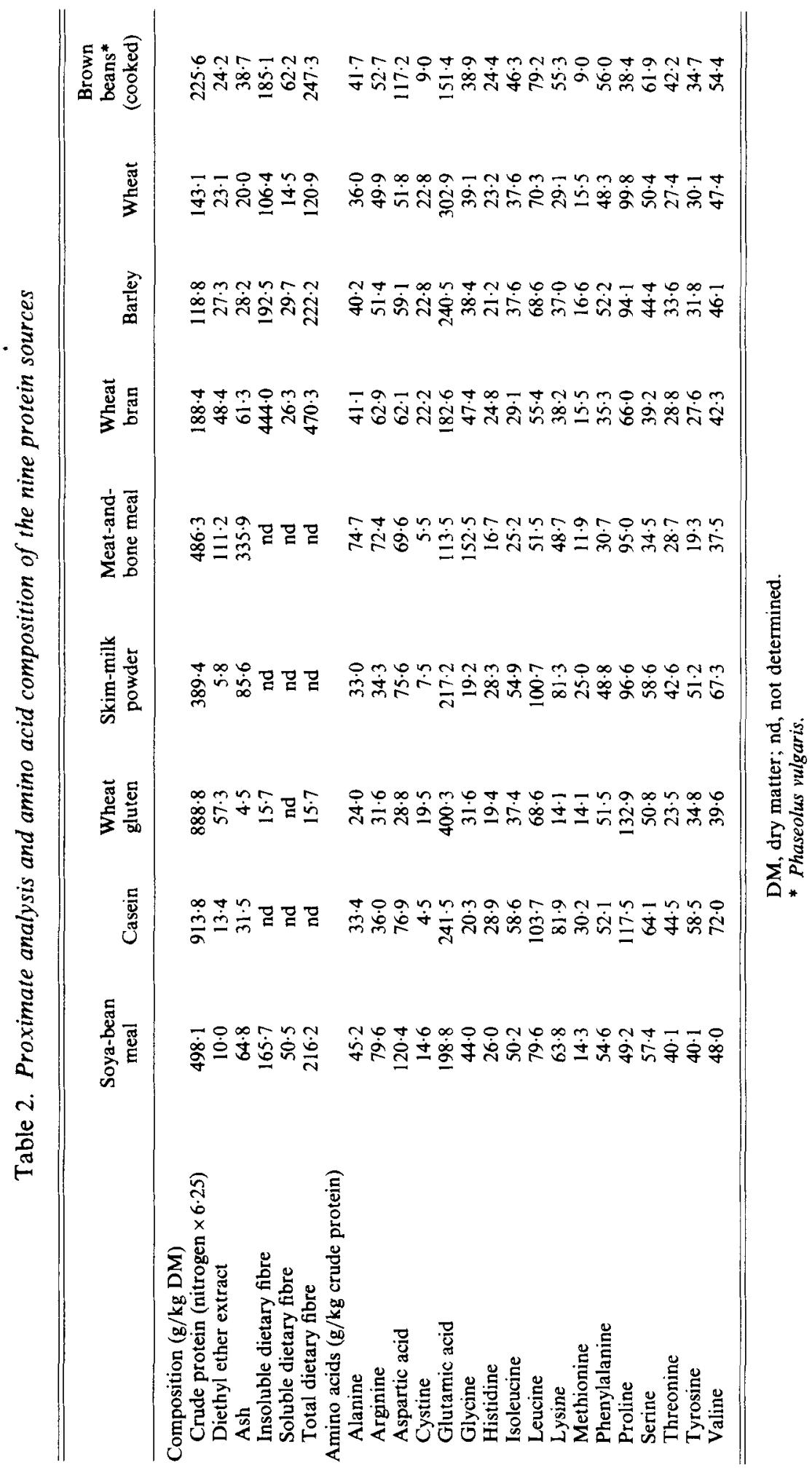




\section{RESULTS \\ Chemical composition}

The proximate analysis and amino acid composition of the nine protein sources are given in Table 2. As can be seen, the values for crude protein $(\mathrm{N} \times 6.25)$ varied from $118.8 \mathrm{~g}$ protein $/ \mathrm{kg} \mathrm{DM}$ in barley to $913.8 \mathrm{~g}$ in casein. The content of fat and ash was relatively low in all samples except for meat-and-bone meal with 111.2 and $335.9 \mathrm{~g} / \mathrm{kg} \mathrm{DM}$ respectively. The fibre content varied considerably from an assumed value of zero in the animal sources to 444.0 and $26.3 \mathrm{~g} / \mathrm{kg} \mathrm{DM}$ in wheat bran of IDF and SDF respectively. It can be seen that the level of IDF was much higher than that for SDF. However, soyabean meal and brown beans both had a relatively high proportion of SDF.

The amino acid composition varied considerably among the nine foodstuffs. Soya-bean meal, casein, skim-milk powder, meat-and-bone meal and brown beans are all assumed to have methionine as the first-limiting amino acid while wheat gluten, wheat bran, barley and wheat are assumed to have lysine as the first-limiting amino acid.

\section{$A D$}

$\mathrm{AD}$ of casein $(0.904)$ and wheat gluten $(0.902)$ was significantly higher than that of the other protein sources, with skim-milk, wheat and soya-bean meal giving intermediate values $(0.867,0.836$ and 0.828 respectively) and barley a slightly lower value $(0.785)$ (Table 3$)$. Meat-and-bone meal and wheat bran had $\mathrm{AD}$ values of 0.720 and 0.715 respectively, while AD of brown beans $(0.604)$ was significantly lower.

The mean effect of dietary modification on $\mathrm{AD}$ was not large. Addition of the first-limiting amino acid caused a mean improvement from 0.775 to 0.793 . Although the response was positive in all cases, it was significant only for soya-bean meal, casein, skim-milk powder, meat-and-bone meal and brown beans, with the largest response being obtained with brown beans, where supplementation resulted in an improvement from 0.560 to 0.604 (Table 4). Addition of antibiotic improved AD values of all protein sources except meat-and-bone meal, wheat bran and barley. The average increase, where this response was significant, was 0.046 , with the largest increase $(0.112)$ occurring with brown beans. An increase of the protein level in the diet improved $\mathrm{AD}$ by an average of 0.033 , with the increase being significant for all protein sources except barley.

\section{$T D$}

Mean TD values for casein and wheat gluten ( 0.995 and 0.998 respectively) were highest, and brown beans (0.702) lowest (Table 3 ). Differences between protein sources were of a similar magnitude to the differences obtained with the AD values. The addition of the first-limiting amino acid improved TD significantly only with casein, skim-milk powder, meat-and-bone meal and brown beans. The mean average increase for all treatments was 0.016 . The mean improvement with antibiotic addition was 0.023 , with this effect occurring only with soya-bean meal, casein, skim-milk powder and brown beans (Table 4). The improvement with brown beans was from 0.680 without antibiotic to 0.777 with antibiotic addition. An elevation of the dietary protein level decreased the mean TD value from 0.887 to 0.876 . However, this reduction was significant only for skim-milk powder, barley and brown beans, with the reduction for brown beans, from 0.680 to 0.638 , being markedly greater than that for any other treatment.

The BV of the protein sources when unsupplemented was greatest for skim-milk power $(0 \cdot 827)$, with values for casein, soya-bean meal, wheat bran and barley all in excess of 0.700 


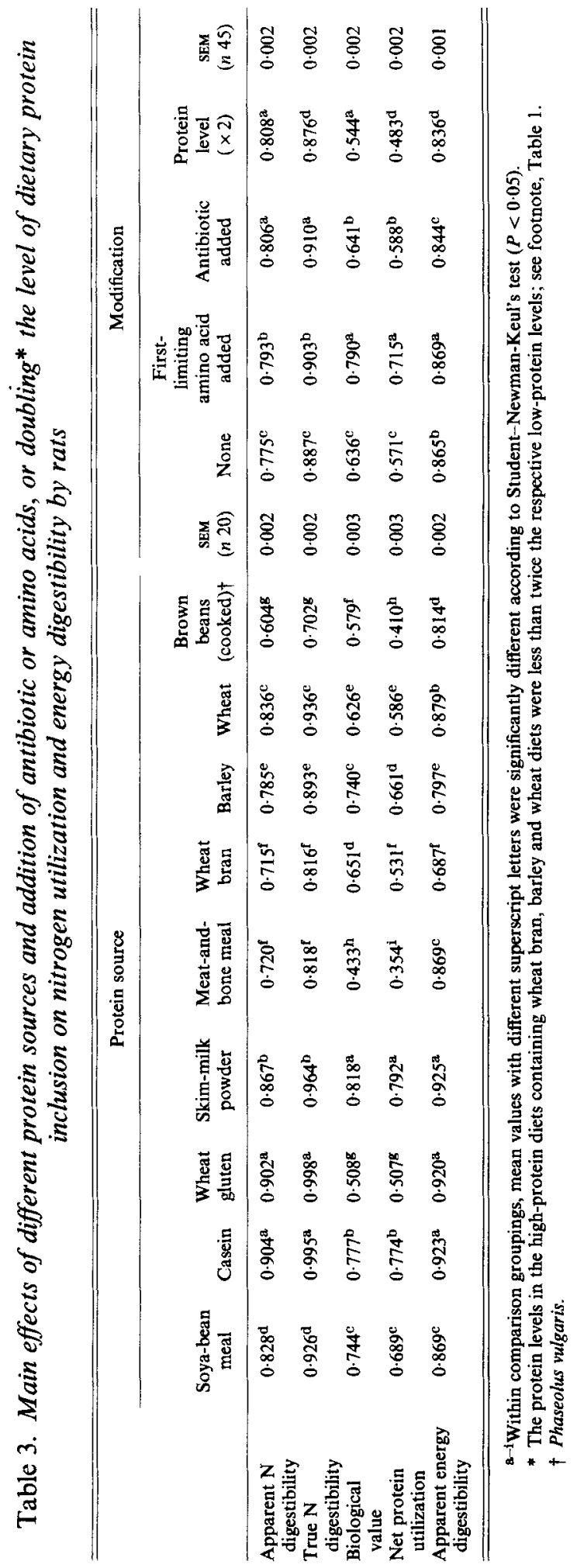




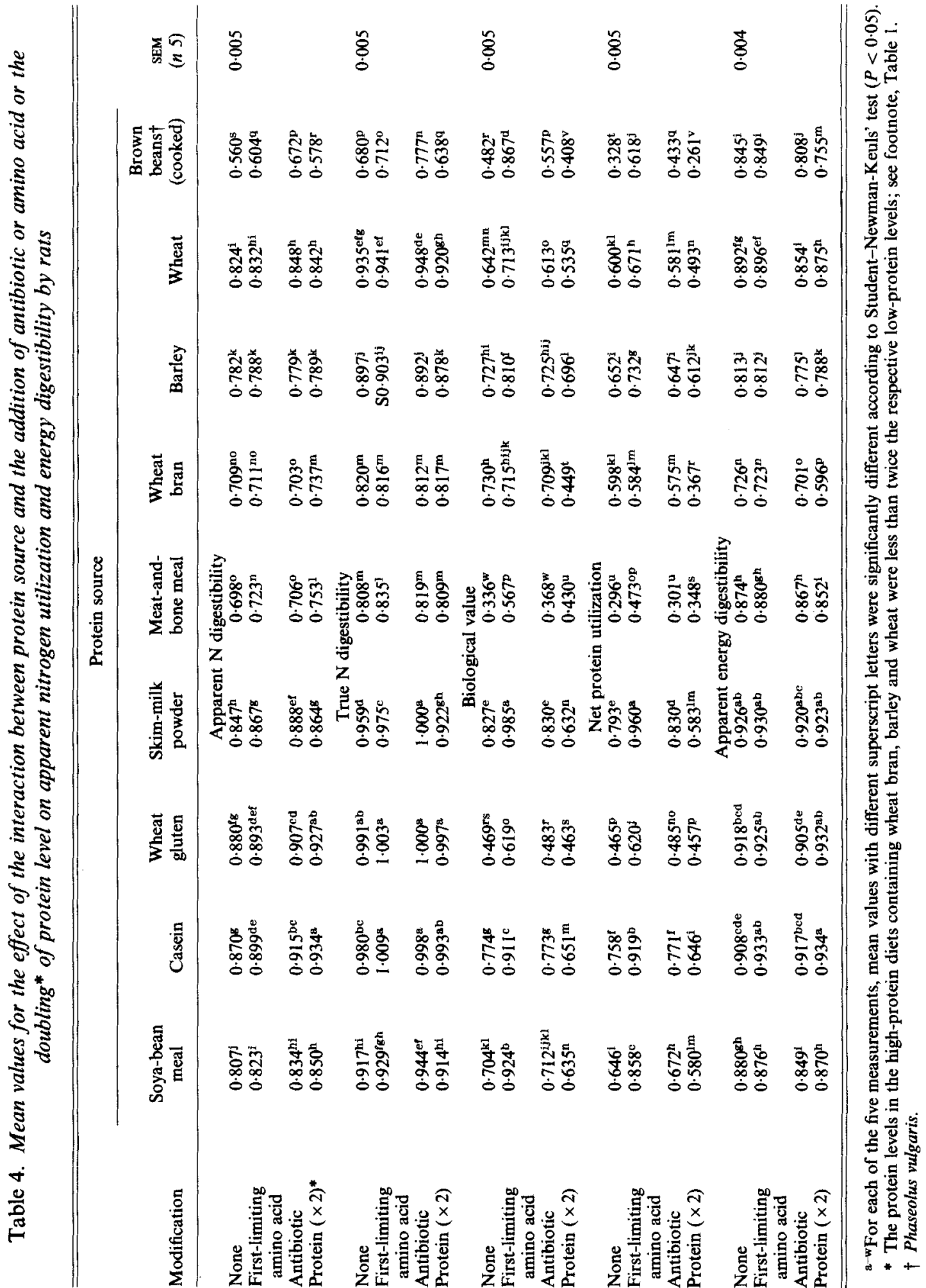


(Table 4). Values for wheat, wheat gluten, brown beans and meat-and-bone meal $(0 \cdot 642$, $0.469,0.482$ and 0.366 respectively) were considerably lower. There was an average increase of 0.154 in BV as a result of the addition of the assumed first-limiting amino acid. An exception was wheat bran, where lysine addition did not effect an improvement, indicating an error in the assumption that this amino acid was first-limiting.

Although the average response in BV to antibiotic addition was small (from 0.636 to 0.641 ) (Table 3), there was considerable variation between responses with the different protein sources (Table 4). Only with wheat bran, wheat and brown beans was the response significant, with a decrease for wheat bran and wheat of 0.021 and 0.029 respectively, but an increase for brown beans of 0.075 . An increase of the protein level, from the conventional $15 \mathrm{~g} \mathrm{~N} / \mathrm{kg} \mathrm{DM}$ to $30 \mathrm{~g} \mathrm{~N} / \mathrm{kg} \mathrm{DM}$, markedly decreased BV for all protein sources except wheat gluten, where there was no change, and meat-and-bone meal, where there was an increase from 0.366 to 0.430 . However, it should be stressed that at the high-protein level the diets containing wheat bran, barley and wheat provided only 25,19 and $22 \mathrm{~g} \mathrm{~N} / \mathrm{kg} \mathrm{DM}$ respectively.

\section{$N P U$}

NPU for the unsupplemented proteins was greatest for skim-milk powder and casein $(0.793$ and 0.758 respectively) (Table 4). Barley, soya-bean meal, wheat and wheat bran produced values ranging from 0.652 to 0.598 . The NPU of wheat gluten was markedly lower at 0.465 , while the lowest values were obtained with brown beans $(0.328)$ and meat-and-bone meal $(0 \cdot 296)$. Values were uniformly increased with the provision of the first-limiting amino acid, with the average increase being $0 \cdot 144$ (Table 3). An exception was found with the lysine supplementation of wheat bran, where there was no increase, presumably because lysine was not first-limiting. Although there was only a small, albeit significant mean response in NPU to antibiotic supplementation, the response was large with brown beans (from 0.328 to 0.433 ) and was in fact significantly negative with wheat bran.

An increase in the protein level was associated with a large decrease in NPU with proteins of medium to high BV (soya-bean meal, casein, skim-milk powder, wheat bran, barley and wheat). With the proteins of lower BV, the response was variable. With wheat gluten, the NPU of 0.469 was not significantly altered; with meat-and-bone meal the value was increased (from 0.296 to 0.348) and with brown beans there was a decrease of the same order as that obtained with the higher-quality proteins.

\section{$D E$}

DE ranged from 0.874 to 0.926 for all except three of the unmodified diets (Table 4). Lowest values were obtained for wheat bran $(0 \cdot 726)$, barley $(0 \cdot 813)$ and brown beans $(0 \cdot 845)$. Provision of the first-limiting amino acid made a significant difference only for casein where there was an improvement from 0.908 to 0.933 .

Antibiotic addition reduced mean DE (Table 3 ), with this effect primarily associated with significant reductions with soya-bean meal, wheat bran, barley, wheat and brown beans among which the average reduction was 0.034 (Table 4). An increase of dietary protein level improved DE only with casein. With soya-bean meal, wheat gluten and skim-milk powder there was no significant effect, while with all other protein sources there was a reduction, with the reduction being greatest for wheat bran (from 0.726 to 0.596 ) and brown beans $(0.845$ to 0.755$)$. 


\section{DISCUSSION \\ Effect of provision of first-limiting amino acid}

The protein sources used in this experiment represented a wide range in terms of TD $(0.680-0.980), \mathrm{BV}(0.366-0.827)$ and DE $(0.726-0.926)$. Consequently, where responses to diet modification were consistent for all treatments, a generalized conclusion can be made with some justification. Such was the case with the provision of the first-limiting amino acid, where TD was increased by an average of 0.016 . The addition of $\mathrm{N}$ either as methionine or lysine would have contributed 0.012 and $0.025 \mathrm{~g} \mathrm{~N} / \mathrm{g}$ dietary $\mathrm{N}$ respectively. If digestibility of purified amino acids is assumed to be complete, the increase in TD could be explained purely on the basis of an additive effect. Predictably, the provision of the first-limiting amino acid would markedly increase BV (Eggum, 1973). The exception was with wheat bran, where the assumption of lysine being first-limiting was presumably incorrect. Threonine is probably the first-limiting amino acid in this product (Eggum \& Beames, 1983; Pedersen \& Eggum, 1983). DE was only marginally improved by the addition of the first-limiting amino acid, suggesting the effect to be no more than that resulting from an increased $\mathrm{N}$ digestibility.

\section{Antibiotic effect}

The response to antibiotic supplementation was more variable and would suggest the involvement of several factors relating to fermentation in the hind-gut. With the method which was used requiring a constant level of $\mathrm{N}$ in the diet $(15 \mathrm{~g} \mathrm{~N} / \mathrm{kg} \mathrm{DM})$, the level of inclusion of the $\mathrm{N}$ source was inversely related to the $\mathrm{N}$ content of that source. The balance of the diet contained a constant level of oil, cellulose, minerals and vitamins. Cooked potato starch was used as the variable filler. Consequently, the level of inclusion of starch was directly related to the $\mathrm{N}$ content of the protein source. With the digestibility of the cooked potato starch being virtually complete in the small intestine (Fleming \& Vose, 1979), this would mean that the indigestible residue reaching the hind-gut on the protein sources of low $\mathrm{N}$ digestibility, low $\mathrm{DE}$, or both, would be relatively high. However, the composition of the material available for hind-gut fermentation would be different in each case, which would help to explain the large differences in response to the addition of antibiotic, the action of which would be to reduce hind-gut fermentation.

Where there were no significant effects of antibiotic on AD, TD, BV and DE it is assumed that hind-gut fermentation was low. For both wheat gluten and meat-and-bone meal, this was the case. Both contain moderate to high levels of protein, with wheat gluten leaving virtually no indigestible residue. It is suggested that the nitrogenous residue from meatand-bone meal, although large, must have been of low fermentability. Results with ruminants would support this suggestion (Orskov, 1982). However, the hind-gut organisms were probably lacking energy.

In the case of casein and skim-milk powder, antibiotic caused an increase in TD, but had no effect on BV or DE. Several experiments (Orskov et al. 1970; Beames \& Eggum, 1981) have demonstrated an increase in faecal $N$ as a result of increased hind-gut fermentation but this has generally been associated with a reduction in urinary $\mathrm{N}$ excretion. Consequently, an increase in TD would be expected to be associated with a concomitant reduction in BV. The fact that $\mathrm{BV}$ was not reduced and that antibiotic supplementation of casein and skim-milk diets consequently improved NPU, would indicate that the degree of absorption of $\mathrm{N}$ in the small intestine was increased as a result of antibiotic supplementation as described for pigs by Just et al. (1980). On the other hand, experiments with rats (Eggum et al. 1979; Bach Knudsen et al. 1982) have shown that the addition of Nebacitin leads to a trebling of the weight of intestinal contents due to accumulation of feed residues or 
endogenous materials, or both, in the hind-gut. This response is more pronounced with very refined diets low in dietary fibre. In association with this effect, it was shown (Bach Knudsen et al. 1982) that the addition of Nebacitin to a diet with $20 \mathrm{~g}$ fibre $/ \mathrm{kg}$ DM caused a decrease in faeces DM of $1.3 \mathrm{~g} / 5 \mathrm{~d}$. This decrease in DM excretion due to antibiotic fortification had a much more pronounced influence on protein digestibility than on DE. Therefore, the reason that Nebacitin in the present study caused an increase in TD, but had no effect on BV or DE when casein and skim-milk powder (refined products) were given, could be due to a slight elevation of DM, rich in N, retained in the hind-gut.

For both barley and wheat, antibiotic had no effect on TD and no effect on BV for barley, while BV of wheat decreased as did DE for both cereals. It is presumed that the undigested $\mathrm{N}$ residues entering the hind-gut were sufficient to supply the fermentative needs of the microbial flora utilizing the fibre and carbohydrate reaching this site, and thus had a positive influence on DE in the untreated rats compared with the Nebacitin-treated ones (Eggum et al. 1984).

It is difficult to develop an explanation for the response of soya-bean meal to antibiotic supplementation. In this case, TD was increased, BV was not altered but DE was reduced. With the lower faecal $\mathrm{N}$ excretion on the antibiotic diet, yet no concomitant increase in urinary excretion, NPU was increased. Soya-bean meal contains a high amount of total fibre $(216.2 \mathrm{~g} / \mathrm{kg} \mathrm{DM})$ as well as SDF which is easily fermented. The positive influence of Nebacitin on $\mathrm{N}$ absorption in the small intestine (Just et al. 1980) was probably higher than the negative effect of the synthesis of $\mathrm{N}$ into microbial protein. As discussed by Mason (1980), net absorption of $\mathbf{N}$ in the hind-gut represents the balance between the processes of degradation and assimilation reached by the microflora during the period of fermentation.

TD of wheat bran was not affected by Nebacitin while BV and DE were both significantly reduced. With the lower fermentation, the reduction in BV would have been associated with a reduced movement of $\mathrm{N}$ into the hind-gut. However, a parallel improvement in TD was not obtained. In earlier work by Eggum et al. (1984) with barley diets, it was also found that Nebacitin had no influence on TD, but BV was significantly reduced. It had been postulated by Eggum et al. (1979) that such a reduction could be an indication of an absorption of microbially synthesized essential amino acids in the hind-gut of animals with normal gut flora, although experiments on the infusion of amino acids into the caecum of the pig have been unable to demonstrate any significant improvement in $\mathrm{N}$ balance as a result of this infusion (Sauer et al. 1977; Zebrowska \& Buraczewska, 1977). In the work of Eggum et al. (1984), it was shown that Nebacitin had a lower negative effect on BV when barley husk was included. As fibre decreases transit time (Raczynski et al. 1982), its addition would allow less time for microbial growth and production of the limiting amino acid in the hind-gut. However, BV of barley in the present study was not affected by Nebacitin, although it was for wheat. Why BV of wheat bran and barley was unaffected by antibiotic while BV of wheat was negatively affected is not understood, but the fibre level is considerably higher in both barley and wheat bran than in wheat.

The response of brown beans to antibiotic supplementation is the most difficult to attempt to explain. DE was understandably lower; however, TD and BV increased markedly. This indicates that Nebacitin must have reduced drastically the synthesis of microbial protein, thereby resulting in higher TD and $\mathrm{AD}$. The higher $\mathrm{BV}$ obtained with rats receiving Nebacitin supports the hypothesis that relatively less amides, urea, etc. are produced and absorbed (Michel, 1966). One can question why brown beans behaved so differently from the other protein sources. The amino acid pattern is very imbalanced, as can be seen from the response in BV (from 0.482 to 0.867 ) to fortification with methionine. Furthermore, the concentration of soluble fibre, which is easily fermented (Cummings, 1981), is substantially higher than in the other protein sources (Table 2). Part of the starch in brown 
beans might also contribute energy to the microflora (Bressani et al. 1982). In agreement with earlier work by Eggum et al. (1979), the microflora in rats do not seem to be able to modify $\mathrm{DE}$ by more than approximately 0.04 units (with brown beans from 0.845 to 0.808 under favourable conditions). However, the corresponding amount of energy is apparently sufficient for the microflora to affect protein metabolism markedly.

\section{Response to increasing the protein level}

As expected, AD was significantly higher when dietary protein concentration was increased. The reason for this is the reducing influence of metabolic $\mathrm{N}$ on faeces $\mathrm{N}$ as protein level increases (Eggum, 1973). The relatively small increases in AD associated with an increase in protein level of diets containing wheat bran, barley and wheat could thus be explained by the fact that it was not possible to double the protein level in diets containing these protein sources. TD was significantly affected by the protein level only in the diets with skim-milk powder and brown beans, with the lowest values at the highest protein concentration. This is not in agreement with the general assumption that TD is independent of dietary protein concentration (Eggum, 1973). The results indicate that $\mathrm{N}$ was a limiting factor for bacterial growth when skim-milk powder and brown beans were given at the lowest protein level ( $15 \mathrm{~g} \mathrm{~N} / \mathrm{kg} \mathrm{DM})$. As discussed previously, brown beans contain high amounts of easily fermentable (soluble) fibre, while skim-milk powder is rich in lactose which is a good energy source for fermentation (Smulikowska et al. 1985).

Except for wheat gluten and meat-and-bone meal, BV was markedly lower at the higher protein level (Table 4). This has been shown previously by Eggum (1973) with casein and soya-bean meal which were provided in increasing concentrations from 50 to $300 \mathrm{~g}$ protein $/ \mathrm{kg}$ DM. However, the present study demonstrates that an increasing dietary protein concentration affects BV very differently from one protein source to another: soya-bean meal -0.069 , casein -0.123 , wheat gluten -0.006 , skim-milk powder -0.195 , meatand-bone meal +0.064 and brown beans -0.074 . In spite of the fact that the differences between the two protein levels were smaller for wheat bran, barley and wheat, BV was still markedly affected (especially for wheat bran, $-0 \cdot 281$ ). The reasons for these differences in response are difficult to explain, but protein digestibility, fermentable energy, transit time and protein quality would have been contributory factors. The drastic reduction in the BV of wheat bran when the protein level was increased might have been due partly to a reduction in transit time because of the increase in dietary fibre. However, energy density would also have been much lower when the proportion of wheat bran was increased. This can be seen from the decrease in DE of wheat bran from 0.726 to 0.596 when its level of inclusion was increased. The rats might have been short of available energy and thus used dietary protein as an energy source. This hypothesis is in agreement with the results of Bach Knudsen (1982) and Bach Knudsen et al. (1984) working with increasing amounts of barley husk in diets given to rats. They found a negative relation between BV and the amounts of dietary barley husk. In the present experiment, BV of wheat gluten and meat-and-bone meal (both poor protein sources) was little affected by a doubling of dietary protein. As discussed by Eggum (1973), the negative regression coefficient between BV and dietary protein level is larger for protein sources of high quality than for protein sources of low quality. This is also to be expected because of the greater ability of the protein of high quality to satisfy requirements.

Increasing dietary protein had only a minor influence on DE of all protein sources except for wheat bran and brown beans. The reason for the drastic reduction in DE when the level of these two protein sources was increased is, as discussed previously, believed to be due to a reduction in transit time (Raczynski et al. 1982). At shorter transit times the microflora will have less time available for fermentation. Furthermore, fibre in wheat bran is only moderately attacked by the gut flora (Nyman \& Asp, 1982). 


\section{CONCLUSIONS}

It is concluded from the present study that the inclusion of the first-limiting amino acid to a protein source does not affect protein digestibility or DE. The microbial activity in the digestive tract affects protein utilization and $\mathrm{DE}$ to a different degree, depending primarily on the level and type of dietary fibre. The effect of level of $\mathrm{N}$ intake on protein utilization is dependent on both protein quality and the fibre concentration of the diet. It cannot always be assumed that TD is independent of dietary protein level, as protein sources rich in fermentable energy tend to have lower TD values when given at higher concentrations. AD will increase with dietary protein level, but to a different degree, depending on dietary composition.

\section{REFERENCES}

Asp, N.-G., Johansson, C.-G., Hallmer, H. \& Siljeström, M. (1983). Journal of Agricultural and Food Chemistry $31,476-482$.

Association of Official Analytical Chemists (1975). Official Methods of Analysis, 11th ed. Washington, DC: Association of Official Analytical Chemists.

Bach Knudsen, K. E. (1982). Zeitschrift für Tierphysiologie, Tierernährung und Futtermittelkunde 48, 90-104.

Bach Knudsen, K. E., Wolstrup, J. \& Eggum, B. O. (1982). Zeitschrift für Tierphysiologie, Tierernährung und Futtermittelkunde 48, 276-287.

Bach Knudsen, K. E., Wolstrup, J. \& Eggum, B. O. (1984). Zeitschrift für Tierphysiologie, Tierernährung und Futtermittelkunde 52, 182-193.

Beames, R. M. \& Eggum, B. O. (1981). British Journal of Nutrition 46, 301-313.

Bjerring, J. H., Greig, M. \& Holm, J. (1975). U.B.C. BMD 10V. Vancouver, British Columbia: Computing Centre of the University of British Columbia, Vancouver.

Bressani, R., Navarrete, D. A., Hernandez, E., Gutierrez, O., Vargas, E. \& Elias, L. G. (1982). In CIQ$D G Q$ 5. Joint Congress Proceedings. pp. 269-287. Kiel, Federal Republic Germany: Christian-AlbrechtsUniversität.

Chalmers, M. I., Grant, I. \& White, F. (1976). Publication of the European Association of Animal Production no. 16, p. 159.

Combe, E. \& Sacquet, E. (1966). Comptes Rendus Hebdomadaires des Séances de t Académie des Sciences 262, 685-689.

Cummings, J. H. (1981). British Medical Bulletin 37, 65-70.

Eggum, B. O. (1973). National Institute of Animal Science Report no. 406, p. 173.

Eggum, B. O. \& Beames, R. M. (1983). In Seed Proteins, Biochemistry, Genetics, Nutritive Value. pp. 499-531. [W. Gottschalk and H.P. Müller, editors]. The Hague, Boston/London: Martinus Nijhoff/Dr W. Junk Publishers.

Eggum, B. O., Beames, R. M., Wolstrup, J. \& Bach Knudsen, K. E. (1984). British Journal of Nutrition 51, 305-314.

Eggum, B. O., Fekadu, M., Wolstrup, J., Sauer, W. C. \& Just, A. (1979). Journal of the Science of Food and Agriculture 30, 177-184.

Fleming, S. E. \& Vose, J. R. (1979). Journal of Nutrition 109, 2067-2075.

Gruhn, K. (1976). Archiv für Tierernährung 24, 85-89.

Hoover, W. H. \& Heitmann, R. N. (1975). Journal of Nutrition 105, 245-252.

Just, A., Sauer, W. C., Bech-Andersen, S., Jorgensen, H. H. \& Eggum, B. O. (1980). Zeitschrift für Tierphysiologie, Tierernährung und Futtermittelkunde 43, 83-91.

Mason, V. C. (1978). 3rd World Congress of Animal Feeding, Madrid, p. 197.

Mason, V. C. (1980). In Current Concepts of Digestion and Absorption in Pigs, pp. 112-129. [A. G. Low and I. G. Patridge, editors]. Reading: National Institute for Research in Dairying.

Mason, V. C., Bech-Andersen, S. \& Rudemo, M. (1980). Zeitschrift für Tierphysiologie, Tierernährung und Futtermittelkunde 36, 311-324.

Mason, V. C., Kragelund, Z. \& Eggum, B. O. (1982). Zeitschrift für Tierphysiologie, Tierernährung und Futtermittelkunde 48, 241-252.

Michel, M. C. (1966). Annales de Biologie Animale, Biochimie, Biophysique 6, 33-46.

Milne, M. D. \& Asatoor, A. M. (1975). In Peptide Transport in Protein Nutrition, p. 167 [D. M. Mathews, editor]. Amsterdam: Elsevier.

Nyman, M.\& Asp, N.-G. (1982). British Journal of Nutrition 47, 357-366.

Ørskov, E. R. (1982). Protein Nutrition in Ruminants, p. 160. London: Academic Press.

Ørskov, E. R., Fraser, C., Mason, V. C. \& Manns, S. O. (1970). British Journal of Nutrition 24, 671-682.

Ostrowski, H. T. (1975). New Zealand Journal of Agricultural Research 18, 13-17. 
Pedersen, B. \& Eggum, B. O. (1981). Zeitschrift für Tierphysiologie, Tierernährung und Futtermittelkunde 45, 190-200.

Pedersen, B. \& Eggum, B. O. (1983). Qualitas Plantarum Plant Foods for Human Nutrition 33, 51-61.

Raczynski, G., Eggum, B. O. \& Chwalibog, A. (1982). Zeitschrift für Tierphysiologie, Tierernährung und Futtermittelkunde 48, 160-167.

Rerat, A. (1978). Journal of Animal Science 46, 1808-1837.

Rerat, A., Lisoprawski, C., Vaissade, P. \& Vaugelade, P. (1979). Bulletin de I Academie Vetérinaire Français 52 , 333-346.

Sauer, W. C., Stothers, S. C. \& Parker, R. J. (1977). Canadian Journal of Animal Science 57, $775-784$.

Smulikowska, S., Eggum, B. O. \& Wolstrup, J. (1985). Zeitschrift für Tierphysiologie, Tierernährung und Futtermittelkunde 53, 225-232.

Stoldt, W. (1952). Fette, Seifen, Anstrichmittel 54, 206-207.

Tao, R., Belzile, R. J. \& Brisson, G. J. (1971). Canadian Journal of Animal Science 51, 705-709.

Zebrowska, T. \& Buraczewska, S. (1977). 2nd International Symposium on Protein Metabolism and Nutrition, Lelystad, Holland, p. 82. 